\title{
Circuit
}

Musiques contemporaines

\section{Jean Papineau-Couture}

Hommage d'un collègue

\section{Clermont Pépin}

Volume 12, numéro 1, 2001

Henri Pousseur : visages

URI : https://id.erudit.org/iderudit/902243ar

DOI : https://doi.org/10.7202/902243ar

Aller au sommaire du numéro

Éditeur(s)

Les Presses de l'Université de Montréal

ISSN

1183-1693 (imprimé)

1488-9692 (numérique)

Découvrir la revue

Citer ce document

Pépin, C. (2001). Jean Papineau-Couture : hommage d'un collègue. Circuit, 12(1),

100-100. https://doi.org/10.7202/902243ar

Ce document est protégé par la loi sur le droit d'auteur. L'utilisation des services d'Érudit (y compris la reproduction) est assujettie à sa politique d'utilisation que vous pouvez consulter en ligne.

https://apropos.erudit.org/fr/usagers/politique-dutilisation/
Cet article est diffusé et préservé par Érudit.

Érudit est un consortium interuniversitaire sans but lucratif composé de l'Université de Montréal, l'Université Laval et l'Université du Québec à Montréal. Il a pour mission la promotion et la valorisation de la recherche. https://www.erudit.org/fr/ 


\title{
Jean Papineau-Couture Hommage d'un collègue
}

\author{
Clermont Pépin
}

Quiconque désirerait rappeler en détail l'apport de Jean Papineau-Couture dans notre monde musical aurait à parler du compositeur, du pédagogue, de l'administrateur et de l'homme d'action. Pour ma part, je m'en tiendrai aux qualités humaines de mon collègue et ami.

J'ai eu le plaisir et le privilège de connaître Jean dès mes années d'études en composition alors qu'il était déjà un compositeur d'expérience. À cette époque éloignée, je parle des années 45-49, nos rencontres avaient lieu lors de concerts, surtout ceux où la musique canadienne était représentée.

Mais c'est surtout après 1955 que j'ai pu, grâce à l'accueil amical de Jean, entrer de plain-pied dans l'activité culturelle du Québec à titre de jeune musicien professionnel.

J'avais désormais l'occasion de travailler avec lui dans divers comités d'organisation et c'est alors que j'ai pu apprécier ses immenses qualités d'homme d'action. Et cette collaboration de longue date a été pour moi l'occasion d'apprécier la facilité avec laquelle on pouvait dialoguer avec lui, et même, parfois, être en désaccord avec certaines de ses convictions, fussentelles d'ordre musical, organisationnel, voire politique.

Plutôt que de souligner l'importance de Jean en tant que compositeur et administrateur, j'ai préféré rappeler ici ses immenses qualités humaines: loyauté, respect de l'autre, capacité d'amitié, détermination dans la réalisation de projets qui lui tenaient à cœur et qui ont profité à beaucoup d'entre nous.

J'apprécie de pouvoir saluer ici bien affectueusement un compositeur qui fut pour moi un estimé collègue et ami. 